\title{
Differential Expression of the Cellular src Gene during Vertebrate Development
}

\author{
MANFRed SCHARTL ${ }^{*, 1}$ and ANGeliKa BaRnekow $\dagger$ \\ *Genetisches Institut, Heinrich-Buff-Ring 58-62 and †Institut für Medizinische Virologie, Frankfurter Str. 107, \\ Justus-Liebig-Universität Giessen, D-6300 Giessen, Federal Republic of Germany
}

Received December 27, 1983; accepted in revised form May 16, 1984

\begin{abstract}
Cellular genes that are homologous to the transforming genes of certain RNA tumor viruses are suspected to play a functional role during normal developmental processes. To investigate this further, we are studying the expression of the cellular homolog of the Rous sarcoma virus transforming gene (c-src) during embryogenesis of fish, frog, and chicken by quantitative determination of the activity of the c-src encoded protein kinase (pp60-urr). The kinase activity from embryos of fish, frog, and chicken displays the same enzymatic characteristics as the kinase from adult animals: It phosphorylates only tyrosine residues in protein substrates, and its activity is relatively insensitive to inhibition by the diadenosine nucleotide Ap4A. During the course of development, the varying kinase activity level reflects differential expression of the c-src gene product. The kinase activity is low during early development, increases dramatically during organogenesis, and decreases thereafter to the level found in adult animals. The kinase activity displays an organ specificity, with brain showing the highest activity in embryos as well as in adults. Muscle, however, shows high activities during organogenesis, but no or barely detectable activity in adult animals. Our data suggest, therefore, that the c-src gene product plays more of a role in differentiation than in proliferation processes during embryogenesis, and that it may act as a pleiotropic effector.
\end{abstract}

\section{INTRODUCTION}

The question of the function of cellular oncogenes (c-onc's) in normal cells has given rise to a variety of theoretical considerations, particularly concerning those c-onc genes, which are homologous to the oncogenes of the acute transforming retroviruses. Reasoning that the action of these viral oncogenes ( $v$-onc's) mirrors the function of the c-onc genes, their cellular counterparts are assumed to be regulators of growth and development, and that they might function mainly during embryogenesis and regeneration processes (Bishop, 1982; Bauer et al, 1982; Anders et al, 1984; Goyette et al, 1983). Experimental data supporting these assumptions are sparse and, at present, equivocal: (1) The c-onc genes homologous to the transforming sequences of Abelson murine leukemia virus (c-abl), Harvey sarcoma virus $\left(\mathrm{c}-\operatorname{ras}^{\mathrm{H}}\right)$, Kirsten sarcoma virus $\left(c-r a s^{K}\right)$, McDonough feline sarcoma virus (c- $\left.f m s\right)$, and Finkel-Biskis-Jinkins murine sarcoma virus (c-fos) were found at the mRNA level to be differentially expresssed in mouse embryonic tissues (Müller et al, 1982; Müller, 1983). (2) The expression of the cellular counterpart to the oncogene of Rous sarcoma virus, $c$ $s r c,{ }^{2}$ has been studied in avian embryos at the protein

\footnotetext{
'To whom correspondence should be addressed.

${ }^{2}$ Abbreviations: c-src, cellular homolog of the Rous sarcoma virus transforming gene; v-src, Rous sarcoma virus transforming gene; pp60 $60^{c-s r}$, gene product of c-src; pp60 $0^{\mathrm{v}-\mathrm{sre}}$, gene product of v-src, Ap4A, diadenosine $5^{\prime}, 5^{\prime \prime \prime}-P^{1}, P^{4}$-tetraphosphate; TBR, tumor-bearing rabbit; RSV, Rous sarcoma virus.
}

level (Barnekow et al, 1981; Barnekow and Bauer, 1984; Cotton and Brugge, 1983). The gene product of c-src, a phosphoprotein of molecular weight 60,000 with a tyrosine-specific kinase activity, was found to be expressed with stage and organ specificity, and high pp60 $0^{\mathrm{c}-\mathrm{src}}$ activity was correlated with the undifferentiated, highly proliferative state of embryonic muscle tissue (Barnekow et al, 1981; Barnekow and Bauer, 1984). (3) Chen et al. reported an organ-specific expression of c- $m y b$, the cellular homolog of the avian myeloblastosis virus transforming gene, in 15- to 19-day-old embryos. (4) Finally during experimentally induced liver regeneration in adult rats an up to fourfold increase in c-ras ${ }^{\mathrm{H}}$ mRNA levels was observed (Goyette et al, 1983).

It is generally expected that these and future studies on the normal function of c-onc genes will contribute to an understanding of their involvement in tumor development and to an understanding of the steps leading to their conversion to activated tumor genes.

The objective of this study was to investigate in detail the expression of the c-src oncogene during ontogenetic development in three different vertebrate classes, namely, fish, amphibia, and birds. For an approach to a functional analysis of c-src, we attempt to relate these data to developmental processes. The c$s r c$ oncogene seems particularly suitable for this type of study as its ultimate gene product, pp60 ${ }^{\mathrm{c}-\mathrm{src}}$, is an enzyme whose level of activity reflects the level of functional gene expression and monitors the amount 
of pp60 $0^{c-8 r c}$ itself (Barnekow et al, 1981; Barnekow and Bauer, 1984; Gonda et al, 1982). The holoblastic development of amphibians has clear advantages for the study of pp60-src kinase activity during early embryogenesis as the early division and determination processes are well defined by this class. Fish and birds are included in this investigation because the meroblastic development of these organisms offers the opportunity to study the expression of $\mathrm{pp} 60^{c-a r c}$ during clearly recognizable stages of organogenesis and histogenesis.

Our data suggest that the c-src oncogene plays a role during ontogenesis in cell and tissue differentiation, rather than solely in cell proliferation.

\section{MATERIALS AND METHODS}

\section{Animals}

Fish. Embryos and neonates were from the livebearing poeciliid fish Poecilia reticulata (Population Rio Helena, Mexico), and Xiphophorus variatus (Population Rio Coy, Mexico). Adults were $X$. variatus, $X$ helleri (Population Rio Lancetilla, Mexico), and Xiphophome laboratory hybrids, all raised under standard conditions in the aquarium of the Genetisches Institut. Developmental stages were classified according to Tavolga (1949).

Amphibia. Freshly spawned eggs of the anurans Rana temporaria and Bufo bufo were collected in waters of the surrounding of Giessen and cultivated in the laboratory at $10-15^{\circ} \mathrm{C}$. Adult Xenopus laevis were purchased from a commercial dealer. Developmental stages were classified according to the stages described by Kopsch (1952) for Rana fusca.

Birds. Specific pathogen-free eggs from white leghorn chickens (Gallus domesticus) were obtained from Lohmann Tierzucht GmbH, Cuxhaven, FRG. In addition, specific tissues as needed were removed from young (i.e., approximately 3 months posthatching) cocks. Developmental stages were classified according to Hamburger and Hamilton (1951).

\section{Preparation of DNA and RNA}

Total high-molecular-weight genomic DNA from testes of Xiphophorus was prepared by phenol extraction, digested with restriction enzymes, size fractionated on $0.8 \%$ agarose gels, and transferred to nitrocellulose according to Southern (1975). RNA was extracted from adult Xiphophorus liver according to the method of Harding et al. (1977). The RNA was enriched for poly $(\mathrm{A})^{+}$RNA by one cycle of affinity chromatography on oligothymidylic acid cellulose, run on denaturing formaldehyde/agarose gels and transferred to a hy- bridization membrane (Gene screen, NEN, Dreieichenhain, FRG).

\section{Hybridization Procedures}

The 600 basepair src-specific Pst fragment of RSVDNA clone SR-A 2 (DeLorbe et al., 1980) was nicktranslated to a specific radioactivity of $0.7 \times 10^{9} \mathrm{cpm} /$ $\mu \mathrm{g}$ of DNA in the presence of $\left[\alpha{ }^{32} \mathrm{P}\right] \mathrm{dCTP}(>3000$ $\mathrm{Ci} / \mathrm{mmol}$ ), and thereafter purified on a Sephadex G-50 column.

All filters were prehybridized and hybridized at $43^{\circ} \mathrm{C}$ in $5 \times \mathrm{SSC}, 50 \mathrm{mM}$ Tris- $\mathrm{HCl}$ (pH 7.5), 0.1\% Ficoll, bovine serum albumin, and polyvinylpyrrolidone; $0.1 \%$ $\mathrm{Na}_{4} \mathrm{P}_{2} \mathrm{O}_{7}, 100 \mu \mathrm{g} / \mathrm{ml}$ of denatured calf thymus DNA, $0.1 \% \mathrm{SDS}$, and $40 \%$ formamide. Of nick-translated probe $7 \times 10^{6} \mathrm{cpm}$ were applied to each filter, and the hybridization was carried out for $72 \mathrm{hr}$. RNA filters were subsequently washed in $2 \times \mathrm{SSC}, 0.1 \%$ SDS at $50^{\circ} \mathrm{C}$; DNA filters were washed in $1 \times \mathrm{SSC}, 0.1 \% \mathrm{SDS}$ at $68^{\circ} \mathrm{C}$ for at least $2 \mathrm{hr}$. The labeled RNA and DNA bands were detected by autoradiography (with intensifying screen at $-70^{\circ} \mathrm{C}$ ).

\section{Antisera}

Antisera from RSV tumor-bearing rabbits (TBRsera) were prepared by simultaneous injection of SRD RSV and Prague C RSV into newborn rabbits in a modification (Ziemiecki and Friis, 1980) of the procedure described by Brugge and Erikson (1977). All antisera used in this study were shown to detect specifically the c-src kinase (see Schartl and Barnekow, 1982).

\section{Preparation of Cell Extracts, Immunoprecipitation, and Protein Kinase Assay}

Total embryos were separated mechanically from the extraembryonic membranes and the yolk. Only freshly excised organs from embryos and adults were used for analysis. The different samples are washed twice with ice-cold phosphate-buffered saline and then mixed with $10 \mathrm{ml}$ extraction buffer $(10 \mathrm{mM}$ sodium phosphate, $40 \mathrm{~m} M \mathrm{NaF}, 10 \mathrm{mM}$ EDTA, 1\% Triton-X100 , and 5\% Trasylol Bayer Leverkusen, FRG as protease inhibitor, $\mathrm{pH} \mathrm{7.0)}$ and then the mixture was homogenized in a Dounce homogenizer (15 strokes at $4^{\circ} \mathrm{C}$ ). The homogenate is centrifuged at $20,000 \mathrm{~g}$ for 60 min and the clarified supernatants used for immunoprecipitation experiments.

Immunoprecipitation and the protein kinase assay were performed as described recently (Schartl and Barnekow, 1982) except that $50 \mathrm{mM} \mathrm{ZnCl}$ instead of $50 \mathrm{mM} \mathrm{MgCl}$ was added to the kinase buffer. 
For the Ap4A experiments, various concentrations of $\mathrm{Ap} 4 \mathrm{~A}$ were added to the washed immunoprecipitates 5 min before the kinase reaction was started by the addition of $50 \mathrm{mM} \mathrm{MgCl}$ and of $\left[\gamma-{ }^{32} \mathrm{P}\right]$ ATP.

For quantitation of the kinase reactions, the radioactive gel bands were cut out and solubilized, and their radioactivity determined by liquid scintillation counting. To confirm that the ${ }^{32} \mathrm{P}$-labeled $53 \mathrm{~K}$ band was indeed heavy chain IgG, aliquots of all samples were run under nonreducing conditions and the majority of the ${ }^{32} \mathrm{P}$ counts was detected in a high-molecular-weight band $>150 \mathrm{~K}$.

\section{Protein Determination}

Determination of protein concentration in the supernatant of the centrifuged cell lysates was carried out on trichloroacetic acid-precipitated aliquots according to the method of Lowry et al. (1951).

\section{Phosphoamino Acid Analysis}

The ${ }^{32} \mathrm{P}$-labeled IgG band of TBR serum-precipitated immunocomplexes of fish, frog, and chicken extracts are cut from the gel, eluted, and processed for twodimensional phosphoamino acid analysis according to the method described by Hunter and Sefton (1980).

The hydrolysates, dissolved in a mixture of $\mathrm{pH} 1.9$ buffer and phosphoamino acid marker $(1 \mathrm{mg} / \mathrm{ml}$ each $)$, are resolved in two dimensions on thin-layer cellulosecoated glass plates (Merck \& Co, Darmstadt, Federal Republic of Germany) by electrophoresis toward the anode at $\mathrm{pH} 1.9$ for $180 \mathrm{~min}$ at $500 \mathrm{~V}$ in acetic acidformic acid ( $88 \%$ by vol) $-\mathrm{H}_{2} \mathrm{O}, 78: 25: 897 \mathrm{v} / \mathrm{v}$ followed by electrophoresis toward the anode at $\mathrm{pH} 3.5$ for 100 min at $500 \mathrm{~V}$ in acetic acid-pyridine- $\mathrm{H}_{2} \mathrm{O}$ 50:5:945 v/v. The markers were detected by staining with ninhydrin.

\section{RESULTS}

\section{c-src and Its Gene Product}

The detection of sequences in cellular DNA, designated c-src, which is homologous to the transforming gene, v-src, of RSV, is well documented in frog, chicken, and other species (Shilo and Weinberg, 1981; Oppermann et al., 1979; Spector et al., 1978; Karess et al., 1979; Parker et al., 1981; Gonda et al., 1982; Shalloway et al., 1981). In this study we report on the detection of v-src homologous sequences in the poeciliid fish Xiphophorus. Total genomic DNA, digested with restriction enzymes, contains several fragments that hybridize to a nick-translated src-specific probe (Fig. 1). The fragments in fish differ in size and number from that in chicken. Owing to the stringency of the conditions used for the hybridization these fragments

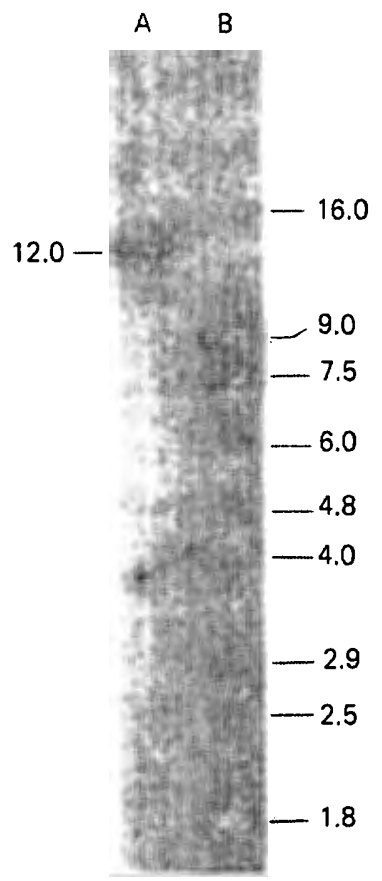

FIG. 1. c-src sequences in chicken (lane A) and fish (lane B). Total genomic DNA was digested with HindIII, size fractionated on a $0.8 \%$ agarose gel, transferred to nitrocellulose, and hybridized to the 600 bp PstI src-specific fragment of the RSV genome. Fragment size is given in $\mathbf{k b}$.

should represent the fish homologs of the c-src gene. The transcriptional product of the fish c-src gene is a $3.0 \mathrm{~kb}$ RNA (unpublished data), as detected by filter hybridization of liver poly $(\mathrm{A})^{+} \mathrm{RNA}$, compared to a $3.9 \mathrm{~kb}$ transcript in chicken (Gonda et al., 1982; Parker et al., 1981). The translation product, a phosphoprotein of molecular weight 60,000 (Barnekow et ah, 1982), the pp60 ${ }^{\mathrm{c}-8 r c}$, is indistinguishable in size from that in chicken (Oppermann et al, 1979; Collett et ah, 1979; Barnekow et al, 1981).

\section{Characterization of a Tyrosine-Specific Protein Kinase in Embryos and Adults of Fish, Frog, and Chicken}

To characterize the $\mathrm{pp} 60^{\mathrm{c}-\mathrm{src}}$ protein kinase in embryos, we took advantage of its ability to phosphorylate the heavy chain of immunoglobulin G (IgG, $\left.M_{w} 53,000\right)$ in immunocomplexes from TBR serum precipitated cell extracts (kinase assay, Collett and Erikson, 1978). A total of three different sera were used throughout the experiments, all with the same results. In cell extracts from all embryos, tested so far, including fish, frogs, toads, and chicken, we could detect a kinase activity, which is reactive with pp60 $0^{c-s r c}$ antibodies.

Two-dimensional phosphoamino acid analysis of ${ }^{32} \mathrm{P}$ labeled IgG of TBR serum precipitated cell extracts 
from fish, frog, and chicken embryos revealed that only tyrosine residues were phosphorylated. No phosphorylation of serine and threonine was observed (Fig. 2).

A further approach to characterize the embryonic pp60 $60^{c-s r c}$ was to follow the effect of Ap4A, a diadenosine nucleotide found in eukaryotic cells and believed to be associated with the regulation of cell proliferation (Rapaport and Zamecnik, 1976) on the kinase activity. Recently we have shown that the viral and the cellular pp60 $0^{\text {sc }}$ kinase exhibits a differential sensitivity to inhibition by Ap4A (Barnekow, 1983). Whereas the pp60 $0^{\text {v-src }}$ kinase activity can be nearly completely inhibited by Ap4A, the pp60 ${ }^{\mathrm{c}-8 \mathrm{rc}}$ kinase activity is relatively insensitive to Ap4A. In this study we have found that in cell extracts from frog and fish embryos the kinase reaction proved to be resistant to $A p 4 A$, similar to the data we obtained earlier with chicken embryos (Barnekow, 1983; Barnekow and Bauer, 1984).

In adult fish, frog, and chicken, immunoprecipitation of brain cell extracts with TBR serum and subsequent performance of the kinase assay proved the specificity of the $\mathrm{pp} 60^{\mathrm{c}-\mathrm{src}}$ kinase for the phosphorylation of tyrosine residues. Furthermore the relative insensitivity against Ap4A could also be observed with the kinase activity precipitated from adult chicken cell extracts or fish cell extracts.

So far, we have not detected any difference in the biochemical properties of $p p 60^{c-s r c}$ from embryos and adult animals.

\section{Differential Expression of pp60 $0^{-s r c}$ Kinase during Ontogeny}

Fish. Unfertilized and just fertilized eggs (stages 0 and 1) showed only hardly detectable kinase activity (Fig. 3a). During the stages of organogenesis and histogenesis (stages 10 to 15), very high activities are found. Beginning with stage 17 the activity of the pp $60^{c-s r c}$ kinase decreases to one-third of this level in the later stages of embryonic development. No significant differences are seen between prehatching stages and neonates. This low level of kinase activity was maintained for at least 6 weeks following birth (Fig. 3a).

Frog. During early embryonic development, until the gastrula stage (stage 6), no significant kinase activity is detectable (Figs. $3 \mathrm{~b}, 4$ ). Low activities are present during neurula (stages 7-8) and in stage 10-11 embryos. The kinase increases up to 20 -fold from the hatching stage (12) to the tadpoles (stages 18-22). This increase is, however, not continously being interrupted by developmental stages displaying lower activities (Figs. $3 b, 4)$.

Similar experiments with toad embryos revealed the same results (data not shown).

Chicken. In embryos prior to somite development (stage 6) kinase activity is very low (Fig. 3c). It increases about 15-fold during the next 3 days of development until late limb-bud stages (stage 24), and this increase was duplicated for a total increase of 30 fold to a maximum kinase activity at the end of organogenesis (stages 31-37). Thereafter it decreases until at the end of embryonic development it is about one-third of this maximal value (Fig. 3c).

\section{Organ Specificity}

All experiments on pp60 $60^{\mathrm{c}-\mathrm{src}}$ kinase expression during embryogenesis were performed with cell extracts from the whole organism. For further analysis we were interested in determining if there is any organ specific expression of the kinase activity. The organ specificity of the pp $60^{\mathrm{c}-8 r c}$ kinase is well documented in fish and chicken (Barnekow et al, 1982; Bauer et al., 1982; Cotton a

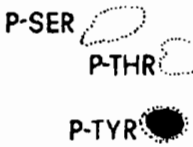

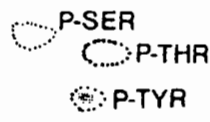

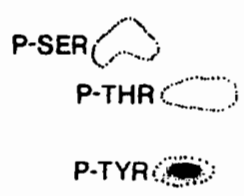

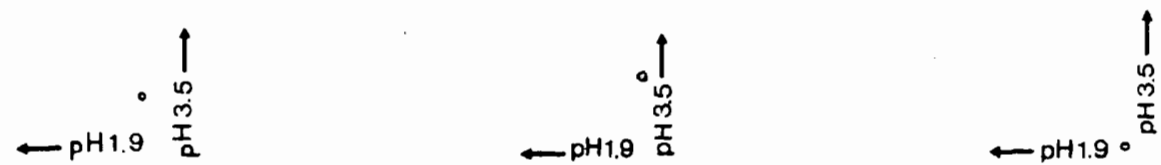

FIG. 2. Two dimensiona! thin layer electrophoresis of ${ }^{32} \mathrm{P}$-labeled heavy chain of TBR-serum precipitated cell extracts. The ${ }^{32} \mathrm{P}$-labeled heavy chain IgG was eluted from the gel, hydrolized, and the phosphoamino acids separated by electrophoresis at pH 1.9 in the first dimension and at pH 3.5 in the second dimension. (A) Chicken; (B) frog; (C) fish. P-ser, phosphoserin, P-thr, phosphothreonine, P-tyr, phosphotyrosine, o, origin. 

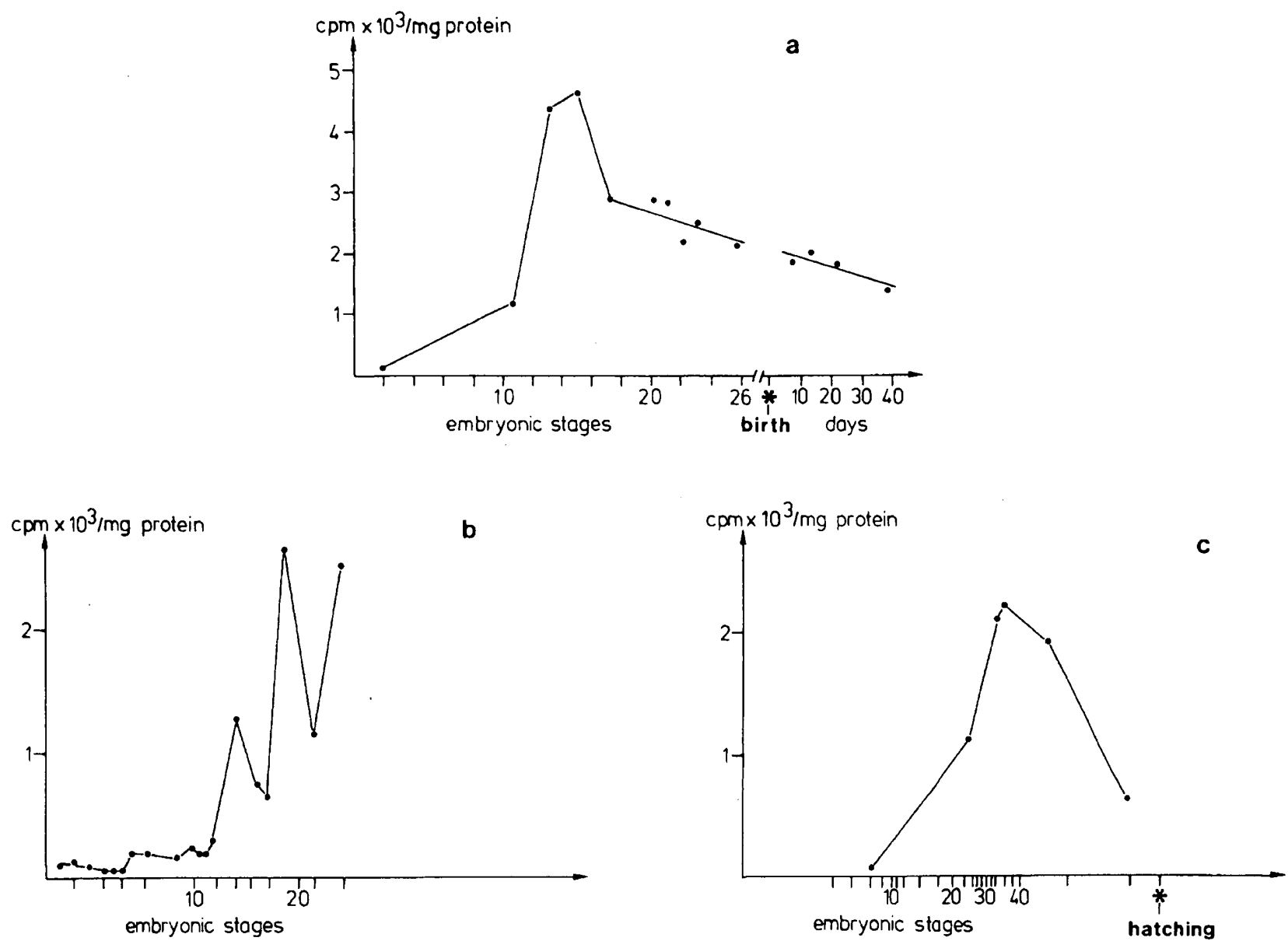

FIG. 3. Kinase activity during ontogenesis of (a) fish, (b) frog, and (c) chicken. All data are mean values of three parallel experiments (standard deviation $<5 \%$ ). The level of background counts was always $<50 \mathrm{cpm}$.

and Brugge, 1983; Barnekow and Bauer, 1984). In this study we confirm these results and report on an organ specificity in frog. In every case, brain cell extracts showed the highest kinase activity (Table 1). Extracts from heart, liver, gonads, and skin displayed lower activities. Fish and frogs show comparable values concerning these organs but differ from chickens. Remarkably, muscle extracts from adult fish, frog, and

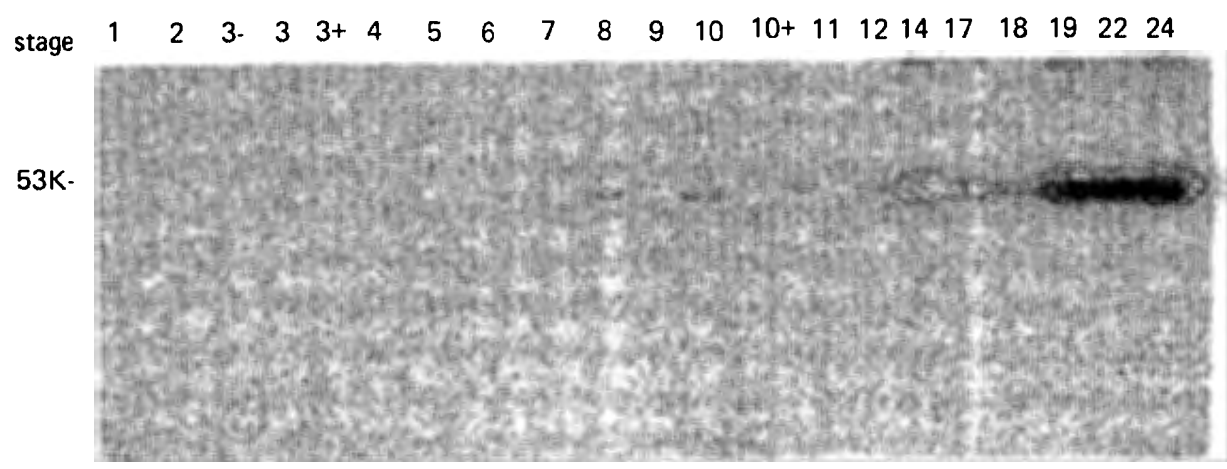

FIG. 4. Kinase activity from a representative experiment in different developmental stages of the frog. 53K, heavy chain of IgG. 
chicken showed either no or barely detectable kinase activity, while in muscle extracts from chicken embryos the activity was nearly as high as in brain (Table 1).

\section{DISCUSSION}

Cellular oncogenes are thought to play a role in ontogenetic and/or regeneration processes. The c-src gene appears first during phylogenesis in the sponges and is presumed to have evolved in concordance with the multicellular organization of the metazoans (Schartl and Barnekow, 1982; Barnekow and Schartl, 1984). In this study we could show that c-src is expressed during fish, frog, and chicken embryogenesis as measured by the pp $60^{\mathrm{c}-8 r}$ kinase activity. The level of kinase activity is not constant during development but shows considerable variation depending upon the embryonic stage. In an attempt to compare the developmental profile of pp60 ${ }^{c-s r c}$ between the three classes, we have made two broad assumptions: We regard the development of fish, frog, and chicken, all members of the subphylum vertebrates, as generally homologous and we place the developmental stages of these three organisms into a common time table. As developmental landmarks for this comparison, we use the following characteristics: development of somites, first appearance of fin and extremity buds, end of organogenesis, development of pharyngeal pouches and gill clefts. The time course of these processes was followed and normalized to the development of the fish Xiphophorus. By plotting the kinase activities determined in fish, frog, and chicken embryos against the so corrected time axes (Figs. 3a, b, c), one sees a striking common tendency: During

TABLE 1

ORGAN SPECIFITY OF pp60 $60^{\text {c-rre }}$ KINASE ACTIVITY

\begin{tabular}{lcccc}
\hline & & & & \multicolumn{2}{c}{ Chicken } \\
\cline { 4 - 5 } Organ & Fish & Frog & Adult & Embryo $^{\circ}$ \\
\hline Brain & $1.000^{b}$ & 1.000 & 1.500 & 1.500 \\
Heart & 600 & 800 & 400 & 600 \\
Liver & 200 & 200 & 1.300 & 450 \\
Gonads & 650 & 550 & 1.400 & n.t. ${ }^{c}$ \\
Skin & 350 & n.t. & n.t. & n.t. \\
Spleen & 500 & n.t. & 1.100 & n.t. \\
Muscle & 100 & 100 & 100 & 1.100 \\
\hline
\end{tabular}

\footnotetext{
a Stage 34.

${ }^{6}$ The kinase activity is specified as $\mathrm{cpm} / \mathrm{mg}$ soluble protein. In order to allow comparison of the data from experiments performed with $\left.{ }^{82} \mathrm{P}\right]$ ATP of differing specific activities, the pp60 $60^{\mathrm{c}-\mathrm{erc}}$ kinase activity of brain extracts from chicken adults and embryos was taken as 1500 $\mathrm{cpm} / \mathrm{mg}$ protein, that of frog and fish brain was taken as $1000 \mathrm{cpm} /$ $\mathrm{mg}$ protein, and all other values calculated relative to this standard. Kinase activity in brain of frog and fish $(n>500)$ is always only twothird of that of the chicken.

' n.t., not tested.
}

early embryogenesis, when the rapid first cleavage divisions occur, and during gastrulation, when threedimensional, invasive growth of undifferentiated tissues occurs, i.e., processes resembling tumor growth, the kinase activity is low. It then increases dramatically during organogenesis in all three organisms, and decreases during late development, as determined in the fish and in the chicken. As the period of organogenesis is characterized more by cell differentiation processes than by rapid cell proliferation, one is tempted to conclude that the pp60 $0^{\mathrm{c}-\mathrm{src}}$ kinase plays a role more in differentiation than in proliferation during embryogenesis.

This statement appears to be contradictory to the proposed role of the viral pp $60^{\text {src }}$, because virus transformed cells are characterized by high proliferation rates. However, if one considers that different stages of differentiation of the same cell type are marked by a different potential for proliferation, with the most highly differentiated cells possessing the lowest proliferative potential, it can be seen that a factor that induces a shift from one stage of differentiation to another might then indirectly also have an effect on that cells proliferative capacity (see Anders et al., 1984).

The activity of the pp60 $0^{c-8 r c}$ kinase was found to be distributed in an organ-specific manner in adult animals and embryos (see also Bauer et al, 1981; Barnekow et al., 1982; Schartl and Barnekow, 1982), and would also seem to imply a specific function for the kinase. It also shows that only some organ systems (in particular the nervous system and muscle) are mainly responsible for the marked increase in pp60 $0^{c-s r c}$ kinase activity during organogenesis. The decrease in kinase activity in late embryonal stages is interpreted as being due to the decrease of activity in the muscle, as shown for the chicken embryo (Barnekow and Bauer, 1984) and supported by the data presented here from adult fish and frog muscle which show barely detectable kinase activity.

Embryonic cells and neoplastically transformed cells share some common features, which distinguish them from normal differentiated cells. This has led to the hypothesis that in some cases transformed cells revert to an earlier stage of differentiation ("retrodifferentiation," Bauer et al, 1982; Uriel, 1976; Bauer and Yoshikawa, 1980), or that they are neoplastically transformed stem cells, that have retained their embryonic character (Anders et al, 1984). In this context it is tempting to speculate that pp60 ${ }^{\mathrm{c}-\mathrm{s} r}$ in embryonic cells may exert a similar but transitory effect on proliferation or the maintainance of a stage of cell differentiation that is compatable with cell division, similar to the action of the viral counterpart, pp60 $0^{v-s r c}$, in transformed cells. 
Increased tyrosine-specific protein kinase activity has been associated not only with neoplastic transformation of cells by avian sarcoma virus (Hunter and Sefton, 1980; Collett et al. 1978) and other viruses (Wand et ah, 1982), but also with the stimulation of specific cell proliferation by certain growth factors and hormones, such as epidermal growth factor (Ushiro and Cohen, 1980; Erhart et al, 1981), platelet-derived growth factor (Ek et al, 1982), and insulin (Kasuga et $a l, 1982)$. Interestingly, it was also found that tyrosinespecific protein kinase activity is dramatically increased during early embryonic development in the sea urchin (Dasgupta et al. 1983). However, the increase of kinase activity of vertebrate embryos occurs relatively much later in development than in the invertebrate sea urchin. Therefore, a systematic analysis of kinase activities in embryos of different phylogenetic descendence may help to determine whether the same kinase is active in both vertebrates and invertebrates and whether the different times of increase of kinase activity reflect a general difference in vertebrate and invertebrate development.

If the increased pp60 ${ }^{\mathrm{c}-\mathrm{s} r c}$ kinase activity in normal cells is of any biological significance, our data as well as those published recently by Cotton and Brugge (1983) demonstrate that such an activity would not be restricted to embryonic cells and not necessarily occur concomitant with cell division. From this functional standpoint, and assuming that the main function of pp $60^{\mathrm{v}-s r c}$ is to induce cellular proliferation, the high level of pp60 $60^{c-s r c}$ kinase activity in the brains of adult animals seems difficult to understand. At this point we have no data regarding a structural or functional difference between adult and embryonic pp60 $0^{c-s r c}$ kinase. However, there is ample evidence for a multifunctional and/or pleiotropic effect of pp60 $0^{v-s r c}$, which induces, for example, such diverse phenomenon as changes in carbohydrate metabolism and the cytoskeletal organization (Bauer et al, 1982). It is possible, therefore, that in nondividing cells only one or another function of $p p 60^{\text {src }}$ is expressed and thus the molecule plays a role that is perhaps qualitatively different from that in transformed cells.

The authors wish to thank Prof. Dr. F. Anders and Prof. Dr. H. Bauer for many helpful suggestions, S. Robertson for critically reading the manuscript, $M$. Gessler for preparing the src-specific fragment, and E. Ossendorf, C. Reitz, and U. Wend for technical assistance.

This work was supported by the Deutsche Forschungsgemeinschaft, Sonderforschungsbereiche 103 ("Zellenergetik und Zelldifferenzierung") and 47 ("Virologie").

\section{REFERENCES}

ANDers, F., Scharth, M., Barnekow, A., and Anders, A. (1984). Xiphophorus as in vivo model for studies on normal and defective control of oncogenes. In "Advances in Cancer Research" (S. Weinhouse and G. Klein, eds.), Vol. 42, pp. 191-275. Academic Press, New York.

BARNEKOW, A. (1983). Effect of several nucleotides on the phosphorylating activities of the Rous sarcoma virus transforming protein pp60 $60^{v-r e}$ and its cellular homologue, pp60 $0^{\text {conc }}$. Biosci. Rep. 3, 153162.

BARNEKOW, A., and BAUER, H. (1984). The differential expression of the cellular src-gene product pp60-orc and its phosphokinase activity in normal chicken cells and tissues. Biochim. Biophys. Acta, 727, 94-102.

Barnekow, A., Bauer, H., Boschek, C. B., FriIS, R. R., and Ziemiecki, A. (1981). Rous sarcoma virus transformation: Action of the src gene product. In "International Cell Biology 1980-1981" (H. G. Schweiger, ed.), pp. 457-465. Springer-Verlag, Berlin.

Barnekow, A., Schartl, M., Anders, F., and Bauer, H. (1982). Identification of a fish protein associated with a kinase activity and related to the Rous sarcoma virus transforming protein. Cancer Res. 42, 2429-2433.

BARNEKow, A., and SchartL, M. (1984). Characterization of the cellular src gene and its gene product in the freshwater sponge Spongilla lacustris. Mol. Cell Biol 4, 1179-1187.

Bauer, H., Barnekow, A., Boschek, C. B., Fris, R. R., and Ziemiecki (1982). The dualism of expression of onc-genes: Transformation versus differentiation. In "Biochemistry of Differentiation and Morphogenesis" (L. Jaenicke, ed.), Mosbach Colloquium 1982, pp. 74-89. Springer-Verlag, Berlin.

BAUER, H., and YoshiKaWA, Y. (1980). Oncofetal antigens as markers for retrodifferentiation in malignant transformation. In "Viruses in Naturally Occurring Cancers," Cold Spring Harbor Conference on Cell Proliferation, Vol. 7, pp. 1231-1238. Cold Spring Harbor Laboratory, New York.

BISHOP, J. M. (1982). Retroviruses and cancer genes. In "Advances in Cancer Research" (S. Weinhouse, and G. Klein, eds.), Vol. 37, pp. 1-31. Academic Press, New York.

Brugge, J. S., and ERIKSon, R. L. (1977). Identification of a transformation-specific antigen induced by avian sarcoma virus. Nature (London) 269, 346-348.

CHEN, T. (1980). Expression of endogenous avian myeloblastosis virus information in different chicken cells. J. Virol 36, 162-170.

ColletT, M. S., and ERIKSON, R. L. (1978). Protein kinase activity associated with the avian sarcoma virus src gene product. Proc. Natl Acad. Sci. USA 75, 2021-2024.

Collett, M. S., Erikson, E., Purchio, A. F., Brugge, J. S., and ERickson, R. L. (1979). A normal cell protein similar in structure and function to the avian sarcoma virus transforming gene product. Proc. Natl. Acad. Sci. USA 76, 3159-3163.

CotTon, P. C., and BRugge, J. S. (1983). Neural tissue express high levels of the cellular src gene product pp60-srr. Mol Cell. Biol. 3, 1157-1162.

DASGUPtA, J. D., and GARBERS, D. L. (1983). Tyrosine protein kinase activity during embryogenesis. J. Biol Chem. 258, 6174-6177.

Ehrhart, J.-C., Creuzet, C., Rollet, R., and Loeb, J. (1981). Epidermal growth factor-stimulated phosphorylation of tyrosine residues on a 120000 dalton protein in mouse liver plasma membrane subfractions. Biochem. Biophys. Res. Commun. 102, 602-609.

Ek, E., Westermark, B., Wasteson, A., and Heldin, C. (1982). Stimulation of tyrosine-specific phosphorylation by platelet derived growth factor. Nature (London) 295, 419-420.

GondA, T. J., Sheiness, D. K., and BiShop, J. M. (1982). Transcripts from the cellular homologs of retroviral oncogenes: Distribution among chicken tissues. Mol Cell. Biol 2, 617-624.

Goyette, M., Petropoulos, C. J., Shank, P. R., and Fausto, N. (1983). Expression of a cellular oncogene during liver regeneration. Science 219, 510-512. 
HAMBURger, V., and HAMILTON, H. L. (1951). A series of normal stages in the development of the chick embryo. J. Morphol 88, 4992.

Harding, J. D., MacDonald, R. J., Przybyla, A. E., Chirgwin, J. M., Pictet, R. L., and M. W. RutteR (1977). Changes in the frequency of specific transcripts during development of the pancreas. J. Biol. Chem. 252, 7391-7397.

Hunter, T., and SeftoN, B. M. (1980). Transforming gene product of Rous sarcoma virus phosphorylates tyrosine. Proc. Nath Acad. Sci. USA 77, 1311-1315.

KaRESS, R. E., HaYwaRd, W. S., and HanafuSA, H. (1979). Cellular information in the genome of recovered avian sarcoma virus directs the synthesis of transforming protein. Proc. Natl Acad. Sci USA 76, 3154-3158.

Kasuga, M., Zick, Y., Blithe, D. L., Crettaz, M., and Kahn, C. R. (1982). Insulin stimulates tyrosine phosphorylation of the insulin receptor in a cell-free system. Nature (London) 298, 667-669.

KopSCH, F. (1952). Die Entwicklung des braunen Grasfrosches Rana fusca Roesel. Thieme Verlag, Stuttgart.

Delorbe, W., Lucin, P., Goodman, H. M. S., Varmus, H. E., and BISHOP, J. M. (1980). Molecular cloning and characterization of avian sarcoma virus circular DNA molecules. J. Virol. 36, 50-61.

Lowry, O. H., Rosebrough, N. J., FARR, A. L., and Randall, R. J. (1951). Protein measurement with the Folin phenol reagent. $J$. Biol. Chem. 193, 256-275.

MÜlleR, R. (1983). Expression of c-onc genes: c-fos transcripts accumulate to high levels during development of mouse placenta yolk sac, and amnion. EMBO J. 2, 679-684.

Muller, R., Slamon, D. J., Tremblay, J. M., Cline, M. J., and VERMA, I. M. (1982). Differential expression of cellular oncogenes during pre- and postnatal development of the mouse. Nature (London) 299, 640-644.

Oppermann, H., Levinson, A. D., Varmus, H. E., Levintov, L., and Bishop, J. M. (1979). Uninfected cells contain a protein that is closely related to the product of the avian sarcoma virus transforming gene (src). Proc. Nath Acad. Sci USA 76, 1804-1808.
Parker, R. C., VARMuS, H. E., and Bishop, J. M. (1981). Cellular homologue (c-src) of the transforming gene of Rous sarcoma virus: Isolation, mapping, and transcriptional analysis of c-src and flanking regions. Proc. Natl. Acad. Sci USA 78, 5842-5846.

RAPAPORT, E., and ZAMECNIK, P. (1976). Presence of diadenosine 5' $5^{\prime \prime \prime}$ $\mathrm{P}^{1}, \mathrm{P}^{4}$-tetraphosphate (Ap4A) in mammalian cells in levels varying widely with proliferative activity of the tissue: A possible positive "pleiotropic" activator. Proc. Natl. Acad. Sci. USA 73, 3984-3988.

SCHARTL, M., and BARNEKOW, A. (1982). The expression in eukaryotes of a tyrosine kinase which is reactive with $\mathrm{pp} 60^{\mathrm{v}-s \mathrm{rc}}$ antibodies. Differentiation 23, 109-114.

Shalloway, D., Zellnetz, A., and Cooper, G. (1981). Molecular cloning and characterization of the chicken gene homologous to the transforming gene of Rous sarcoma virus. Cell 24, 531-541.

SHILO, B.-Z., and WEINBERG, R. A. (1981). DNA sequences homologous to vertebrate oncogenes are conserved in Drosophila melanogaster. Proc. Natl Acad. Sci. USA 78, 6789-6792.

SOUTHERN, E. M. (1975). Detection of specific sequences among DNA fragments separated by gel electrophoresis. J. MoL Bioh 98, 503517.

Spector, D. H., Baker, B., VARmus, H. E., and Bishop, J. M. (1978). Nucleotide sequences related to the transforming gene of avian sarcoma virus are present in DNA of uninfected vertebrates. Proc. Nath Acad. Sci. USA 75, 4102-4106.

TAvolga, W. N. (1949). Embryonic development of the platyfish (Platypoecilus), the swordtail (Xiphophorus) and their hybrids. Bull. Amer. Museum Natural Hist. 94, 161-230.

URIEL, J. (1976). Cancer, retrodifferentiation, and the myth of Faust. Cancer Res. 36, 4269-4275.

USHIRO, H., and COHEN, S. (1980). Identification of phosphotyrosine as a product of epidermal growth factor-activated protein kinase in A-431 cell membranes. J. Biol. Chem. 255, 8363-8365.

ZIEMIECKI, A., and FrIIS, R. R. (1980). Simultaneous injection of newborn rabbits with the Schmidt-Ruppin and Prague strains of Rous sarcoma virus induces antibodies which recognize the pp60 $60^{\text {arr }}$ of both strains. J. Gen. Virol. 50, 211-216. 